\title{
Effect of Retained Earning Finance on Profitability of Kenyan Petroleum Firms
}

\author{
Dr. Motanya Omai Daniel, PhD \\ Department of Finance \\ School of Business \\ Jomo Kenyatta University of Agriculture and Technology (JKUAT) \\ Kenya
}

\begin{abstract}
The petroleum sector in Kenyan is highly regulated by the government such that, the government sets all prices for most energy products. It is expected that the increased number of petroleum marketing companies over time is as a result of good returns in the sector but there opposite going by happenings in the market. The study's main objective was to assess the effect retained earnings as a source of finance on profitability of petroleum companies in Kenya. A positivist philosophy was adopted to enable testing of the study hypothesis. The study adopted cross-sectional survey design with criterion sampling being used to arrive at 35 firms' between 20072016. Primary data was collected by use of questionnaires along with secondary data. Descriptive statistics and Univariate tests (t-test and Pearson correlation) were carried out. The results indicated an inverse and insignificant relationship between retained earnings finance and profitability at $1 \%$ significance level. This is evidenced by the beta coefficient of -0.018 and a corresponding p-value of 0.975 under equations 1 . The results signify that during the period of study, increasing use of retained earnings finance did not increase or reduce the profitability of petroleum firms in Kenya; implying an improvement in their financial status.
\end{abstract}

Keywords: Retained Earning Finance, profitability, Shareholders, Preference shares

\section{Introduction}

Globally, recent studies on financial structure and profitability have demonstrated that firms operating in a highly competitive environment like the petroleum industry have over time shown that profitability is not guaranteed due to stiff competition and the oligopolistic nature of such industries. Bhutta \& Hasan, (2013) contends that a financial structure is an instrument that concerns itself on decision making about components of both capital and short-term financing. A suitable financial structure goes a long way in ensuring that the firm has adequate cash flows to meet its financial current and long term obligations (Akoto et al., 2013). The petroleum sector is divided into three main sectors based on the steps from drilling to refinement; the upstream sector, midstream sector and downstream sector respectively.

The upstream sector involves the exploration activities and production operations of the crude oil. Midstream involves storing, transporting and distribution of the crude oil while downstream is composed of the refinery of the crude oil and natural gases before distribution and selling of the finished products. Wamugo, et al., 2014) observed that balancing between liquidity and profitability is a major dilemma for most managers. Explaining why most firms have not found or formulated an appropriate financial structure that could maximize their profits. On the other hand, Jape \& Korde (2013) contend that corporate finance focuses on the main decisions about financial investment, issuance of dividends and financing which, has resulted into greater attention being put on long term investment (capital structure) than on financial structure which addresses both current and long term aspects of corporate finance. The uniqueness of the energy petroleum sector arises from the fact that it is very significant as it a strong pillar to economic performance in Kenya, due to the fact that, the sector drives other industries by proving energy without which other industries can't operate (IEA, 2014).

In Kenya, the energy sector is highly regulated characterized by price caps, bond payment at point of entry to ensure energy imports reach desired destinations and through other social-economic mechanisms that are meant to be strictly adhered to. Additionally, the sector depends on raw materials like; crude oil, natural gas and other specialized equipment that are all imported and are significantly affected by international price fluctuations making profitability in the sector almost a pipe dream in a competitive and demanding sector.

\section{Petroleum Firms in Kenya}

Just like elsewhere globally the petroleum sector in Kenya is always faced with numerous challenges. The hostile business environment has been made worse by the introduction very strict and tough tax regime. Usually KRA imposes an upfront payment of 50\% taxes on imported petroleum products. Besides the above there is the requirement that imported crude oil must be supplied by a petroleum marketing firm so as to minimize related costs. This meant that the PMCs must have good cash flow to enable them buy the petroleum products and pay the upfront taxes as per the Petroleum Amendment Act, 2006. 
The petroleum sector in Kenya is comprised of both the local firms and the multinational corporations. The industry is regulated by the Energy Regulatory Commission (ERC) a body that is tasked with ensuring fairness and quality within the industry. The sector is mainly an oligopolistic structure with a few key players. For example in the petroleum sector in Kenya the market is dominated by Total Kenya, Vivo energy and Kenol Kobil at $21.7 \%, 18.9 \%$ and $13.9 \%$ respectively (PIEA, 2014). The energy sector is very competitive and mainly characterized by controlled prices done by ERC, strict taxation frame work besides products that are more of the same which is compounded by a less controlled economy that all calls for serious strategies other than pricing to enhance profits (NSE, 2014).

By the fact that Kenya still imports all petroleum products, profits in the energy sector depend on identification of relevant factors that influence returns like the financial structure, capital structure and working capital. As the failure of companies to be profitable may contribute to disruption of their marketing and distribution consequently leading to industrial actions, blacklisting by suppliers and even bankruptcy of the petroleum marketing firms. Important to note is that the main challenges facing the energy sector range from high operations cots, poor infrastructure, excess regulation, volatility in exchange rates, tax administration and burden of government which all have made profitability an uphill task in the industry (Baffes et al., 2015).

\section{Statement of the Problem Statement}

Petroleum firms operate in a highly competitive environment a fact that compromises firm profitability as the competition is stiff and oligopolistic in nature in the industry. There is need for internal adjustments with a potential of increasing profits for instance the financial structure (Sheik \& Wang, 2013). The above scholars agree on a correlation of the financial structure and the profitability if a company in the developing countries. However, not all findings agree with this argument as other researchers have not found a correlation of the financial structure to the profits of the firms (Muchiri, 2014).

Studies in different countries have shown that, the financial structure affects profits differently depending on the industry under study. Regionally, studies conducted have shown a significant difference in the relationship between financial structure and firm profitability with findings varying depending on the industry and country of the study (Khan, et al., 2012). An analysis in Kenya on the movement of annual gross margin profits before and after price regulation has shown decline in gross profit margin from the year 2010 to 2014 for Total Kenya, Kenol Kobil, National Oil Corporation of Kenya and Hash Petroleum who are all leaders in the industry (KIPPRA, 2015).

With numerous studies having been conducted both in kenya and in the rest of the globe, not much has been done in terms of the effect of the financial structure on profitability of petroleum firms in Kenya, further research has shown that petroleum marketing firms have continued to experience poor returns due to the fact that the industry is highly regulated leading to systematic decline in profits as formulae used by ERC to price products doesn't cover all components. Other studies by Gakure et al., (2012) investigating the significance of the financial structure on performance of manufacturing companies at the NSE; Omesa, et al., (2013) on the role of financial stricture on financial performance among 20 manufacturing firms and Nyabwanga et al., (2012) on the relationship of financial structure on performance of SMEs in Kisii county. Despite the carrying out of the researches on the effects of financial structure and profitability of a firm in Kenya, such studies have not been carried out in the petroleum industry. Besides the above, as Kenya is keen on becoming an industrialized economy by 2030, petroleum marketing companies which are key in the provision of energy must be profitable enough to enhance sustainable development in the sector and other sector likewise as the sector is a fundamental pillar in the growth of other sectors (Ngniatedema \& Li, 2014). Another rationale is that multinational firms like AGIP, Kenol Kobil and Shell \& BP have either attempted or exited the Kenyan market citing profitability challenge as the main cause (Kimeli, 2012), therefore it is rational to conduct a study that was to point towards a reverse to the exit plans besides through sustainable profits.

\section{Objective of the Study}

To investigate the effect of retained earning finance on profitability of Kenyan petroleum companies in kenya.

\section{Literature Review}

This section will be comprised of the tradeoff theory and how it supports the study besides various studies carried out by various scholars as illustrated below:

\section{Trade-off Theory and Retained Earnings}

This theory upholds the assertion that, the organization sets a target in terms of debt and capital share ratios. 
Further it seeks to point out that when decisions on investments of the firm are constant, it encourages an optimal financial structure which is thus achieved at the point where benefit of tax is equal to leverage costs associated with financial distress and bankruptcy (Myers, 2001). Further still it argues that enterprises seek to use debt more often as it is an objective way of guarding against bankruptcy besides management effectiveness and efficiency (Sheikh and Wang, 2011). The theory thus proposes that business enterprises may at times deviate and fail to raise targeted capital structure and hence exhibit an adjustment on their behavior (Abdeljawad, Nor, Ibrahim \& Rahim, 2013).

This theory postulates that more profitable companies are associated with lower bankruptcy costs. Thus, such firms are also able to maintain a higher debt level. The positive relation between profitability and leverage finds confirmation in several researches (DeAngelo \& Masulis, 1980; Jensen, 1986). Alternatively, the dynamics of this theory suggests that leverage is negatively associated to profitability mainly due to the fact that companies could finance their activities with accumulated internal funds, such as retained earnings.

Thus, generating higher operating profit would support company's decision to reduce its debt financing. Furthermore, recent researches discuss the negative correlation between profitability and debt levels, pointing out that if a company becomes more profitable and thus, more valuable, while still maintaining fixed debt level, its debt ratios would become lower (Titman \& Tsyplakov, 2007).Subsequent empirical studies on this theory have found concrete evidence that is in support of the trade-off theory (Frank \& Goyal, 2008). Besides the above, Deesomsak et al., (2004) found out that there is evidence which confirms the assumptions of this theory and can thus influencethe financial structure of the concerned firms.

De-Haan and Hinloopen (2003) examined the different assertions as provided by the trade-off theory, it was argued that there is an empirical support which underscores the importance of this theory as it is a key determinant in the financial structure of choice. Karadeniz et al., (2009), and Huson et al., (2009) have all argued in favor of this model besides concluding that the model possess more explanatory power when compared to other models. Javed et al., (2012) in their study to unearth the various determinants of both long-term and short-term debt, they found a remarkable difference between the assumed determinants and the components of the issued debts.

A short-term debt is preferred by a company having a higher growth potential. They also prefer debts with fewer conditions on the planning of the firm. This preference allows the firm to have a great deal of flexibility in its financial structure. For firms having enough fixed assets, they find ease in generating finances from external sources. They do this in an easier manner as compared to firms with insufficient fixed assets. Thus, they can get the finances at a lower cost or interest when compared to a smaller firm. This phenomenon matches the premises of the tradeoff theory. Nevertheless, firms with high profit margins can prefer internal means of finance generation towards funding their business. This move goes in line with the pecking order theory. These outcomes therefore prove the effects of inertia and industry-specific effects, which form a healthy choice to the estimation techniques (de Jong et al, 2008).

However, there is a gap in the explanation the conservative business nature by this theory, more especially when the business is using funds from debt(s). There is no explanation of why taxation system is affected by the leverage. Popescu (2009) notes that the optimal debt of a business may depend on the cost of bankruptcy and the tax advantage achieved. At this point of exchange, the present marginal tax value on the extra debt is equivalent to the additional costs of the present value of the financial distress (Owalobi \& Anyang, 2013).

Further this theory notes that time has a role that it plays in aspects that typically that are assumed in asingle-period model, this is clear particularly in the roles and functions expected besides the related costs (Luigi \&Sorin, 2009). In this model, suitable finance decision depends on the finance margin anticipated in future periods. Some companies are expected to pay funds in the next financial year, as other firms keep on expecting to raise finances they can raise such from either debt or even share capital (Luigi \& Sorin, 2009).

This theory therefore proposes that at times a firm may use alternative sources of financing to build an optimum structure due to managerial characteristic and behaviour (Abdeljawad, Nor,Ibrahim \& Rahim, 2013). Such presumed targets exist as a requirement to address deviations form set targets of debt.

This deviation could be due to a number of reasons for instance time value which may create uncertainty. Prudently, adjustments should be done when the deviation cost exceeds or is more than relevant cost of making adjustments (Fischer, Heinkel \& Zechner, 1989).

Such deviations are slowly eliminated gradually with time so as to ensure that the firm converges to the targeted financial structure for that time as appropriate. But what is clear is that the magnitude of such actions is very different for different firms (Frank \& Goyal, 2007). Abdeljawad et al., (2013) argues that the percentage deviation in terms of the preferred financial structure can deal with deviations in cash for that period. This theory however assumes that there exist an observable target which in practice is difficult to determine. 
Dynamic trade-off models is very useful when considering other available options found and reflected in the decisions made as compared to decisions made. Goldstein, Ju and Leland (2001) observed that a business entity with low debt levels currently enjoys a priverage of increasing the debt over time.

Thus it is assumed that earnings before tax is irrelevant as chances in the financial structure are influenced by the prevailing financing policy of the firm, an alternative to increase debt in the coming days is purely dependent on future whether such a move will serve the interest of the firm.

This assumption that the earnings before interest and tax can be a source that generates funds to the firm hence increased firm value. It usually runs independent of the EBIT flow as expressed and distributed among those that claim such a practice. An assumption that any cash payout either in terms of taxes, interest paid or even dividends paid usually affects the firm just like the in common reality. According to Luigi and Sorin (2009), there comes out is that the dynamic model adopted considers tax savings expected as compared to bankruptcy costs (Brennan and Schwartz (1984). Both analyzed the continuous time-model with which was uncertain.

They observed that since firms had different reactions to the shocks that were adverse in nature hence need to rebalance without incurring cots, hence they concluded that to maintain desirable level of debt one has to take advantage savings from taxes. This view however may not hold in practice since firms will always incur transaction costs which were ignored in their model. It is clear that the theory thus predicts that tangible assets can shield a firm from more taxation burden hence need to accumulate reasonable if not high leverage debt ratios. Firm that has more intangible assets and whose value is likely to disappear if liquidation takes place, must ensure that they depend more on share capital. For the case of profits it is clear that, trade-off theory will be critical in predicting the returns in terms of profits so as to shield the firm against the tax burden. Under trade-off theory it should be understood that companies that have higher growth opportunities should endeavor to borrow less to lessen chances of more losses in case of distress.

\section{Effect of Retained Earnings Finance on profitability of Petroleum firms}

As far as this study is concerned, retained earning refers to the part of trading profits which is advanced as dividends but is retained by directors for future expansion of the firm (Dinayak, 2014). Campbell (2012), argues that main reason behind retained earnings is more to do with the increasing the chances of growth. Retained earnings are usually recorded under shareholders' equity on the balance sheet (Dinayak, 2014). Also related with periodically retained earnings is the accumulated retained earnings, which are computed by adding net income to (or subtracting any net losses from) beginning retained earnings and subtracting any dividends paid to shareholders (Dinayak, 2014).

Retained earnings is the injection back to the firm for reinvestment from previous financial years (Poker, 2011). Retained earnings is usually expressed in percentage form. When the percentage is high it shows that the firm can perform better and the vice versa is true. Business enterprises exist for the purpose of creating value different stakeholders ranging from; shareholders, those with investments in the firm, clients both internal and external, employees, among others (Ball, 2013).

All revenue that have been retained from profits generated from previous years and thus re invested into the firms operations (Chasan, 2012). The source has also been considered preferable financing option numerous countries. Using the net book value as an objective measure, debt is divided over the capital value. Thus the net book value of loans is calculated as total loan adding interest accrued. The other ratio used is called capital ratio which is calculated using financial debt which is the total leverage to total assets also, such is calculated as the net book value ratio to total leverage compared to assets to total assets. Retained earnings have also been explained as a ratio, commonly known as retention ratio of plowback ratio.

The retention ratio is also known as the retention rate of an organization (Orwel, 2010). While supporting the same notion Chasan (2012), states that there is management has not agreed on what needs to be retained in relation to firm earnings. Gul (2012) carried out a study in Pakistan on the effect of retained earnings on shareholders' wealth. The study sampled 72 companies listed on the Karachi Stock Exchange from 2005-2010.

The study employed multiple regression and stepwise regression method respectively to study the impact of dividend policy on shareholders' wealth. It was found out that there is a significant difference between shareholders' wealth for firm that pay dividends as compared with those that don't. Besides the above, findings also indicated that the wealth of the firm can significantly increase when comparing to those firms that don't pay.

Timothy and Peter (2012) in their study on the relationship between dividend payout and profitability in listed companies at NSE between 2002 - 2010. The scholars using regression analysis established that there is a significant relationship between dividends payment and firm profitability. The findings also indicated that dividends payment was a major factor that influenced return on assets. 
It is normal that managers prefer the firm to retain more to ensure growth as current potential opportunities as perceived by management can be taken advantage of through utilization of what has been given back to the business. On the other hand shareholders would prefer lower retentions as it affects them in terms of dividends paid to them hence for them whenever there is a retention there is a sacrifice that is always made.

Orwel (2010) acknowledges as much as retained earnings is a cheap and convenient way of addressing the existing financial gaps which comes with numerous advantages ranging from ensuring internal ownership is diluted through share capital issue and even that a firm is not exposed to bankruptcy challenges that the company may be exposed to in case of external borrowing especially if the firm is unable to service the loan. However, it must be clear that retained earning denies the investors an opportunity to earn what fairly they are entitled to besides the fact that when a firm uses retained earning it fails to consider opportunity cost aspects (Chasan, 2012).

\section{Research Methodology}

This study employed the positivist philosophy drawn from the natural sciences was applied. The philosophy comprises of the research hypothesis test. The hypothesis is developed from the theories andit is deductive. The testing is was done through the observation and the measurement of the social realities (Saunders et al., 2009). Positivism is founded and has a foundation build on values of reason, truth and validity besides being based on purely on data that is collected and measured in an empirical manner through use of quantitative and qualitative methods respectively (Wooldridge, 2012).

Beck (2003) describes that a research design is a plan that has details on how to find answers of the research objectives and research hypothesis respectively besides addressing any other challenges that were encountered during the study. Lavrakas (2008) notes that a research design is usually made up of the research structure, study frame work besides a study Blueprint that guides the formulation of the research at different stages, as from the hypotheses up to findings and conclusion before a report is made. Therefore what comes out clear is that a good research design is logical in nature and flows a particular sequence when conducting data collection and data analysis so as to ensure that proper procedure is followed (Kothari, 2004).

Descriptive research design is adopted when describing the given situation a phenomena, it takes into consideration current believes customs and also traditions in data collection (Baumgartner, Strong and Hensley 2002). Further, descriptive research also includes surveys and different enquiries with the main reason being that while conducting a descriptive cross sectional research to the research to describe the state current state of affairs objectively (Kothari, 2004).

This study had a target population that comprised of two levels namely; the institutional

level population that was made up of 35 Kenyan petroleum marketing firms that have been consistently operational between 2007 and 2016. The other second level was the finance managers or their respective designees. Finance managers were selected since they are directly responsible in the formulation, adoption and implementation of different financial structures that any firm adopts at a given time besides being responsible for managing finances and other relevant action plans.

It is also paramount to appreciate the fact that, the firms under consideration in this study were categorized in the same industry, where by the petroleum marketing firms had also similar reporting patterns, design and the bare minimum disclosures expected of them by the ERC -their regulator.

Sampling frame is a technical term used to describe a list of the elements that forms the sample population (Mugenda and Mugenda, 2003 and Kothari, 2004) the scholars further point out that the sampling frame consists of all the study elements in the selected study universe (Cooper \& Schindler, 2006).

The petroleum marketing firms and their respective finance managers were the units of analysis while the financial statement were the units of observation, it is therefore clear that descriptive cross sectional design was adopted because it enabled the researcher to gather sufficient data for the study. Sampling frame for this study was made up of 35 petroleum marketing firms that have been in operation between January 2007 and December 2016 as listed in the Energy Regulatory Commission database besides as laid out Primary and secondary data was collected because the two sources of data are meant to reinforce each other (Stiles and Taylor, 2001).

The data was largely quantitative in nature. Primary data were collected using a semi structured questionnaire. The questionnaire comprised of closed ended questionnaires as well as a few open ended ones guided by the concepts of the study, theory and other previous studies. A five point Likert scale ranging from not at all (1) to (5) a very large extent was used to construct some of the items. Secondary data was collected by panel method where a series of data from the annual audited financial statements of the target companies were reviewed. The time series observed was from 2007 to 2016 while the sources of data were the targeted petroleum marketing companies. 
Of interest to the researcher was the annual income statement and the statement of financial position besides the statements of equity of the targeted firms. In this study, assets, total liabilities, short term/current liabilities, retained earnings besides other shareholders' funds and profits after tax were obtained through use of the data collection sheet in the annexure.

Primary data was collected by administering questionnaires to the petroleum marketing firms finance managers in each of the 35 firms. Two research assistants were engaged for the purpose of assisting the researcher to carry out self-administration of the questionnaires. In cases where the assistant researchers were faced with challenges the main researcher addressed this by making personal follow through telephone contacts as provided in the appendix. The entry points used for the firms in question was majorly through the public relation officer the customer service departments of the targeted firms. Louis, Lawrence and Morrison (2007) acknowledges that primary data helps address the original study problem as it gives firsthand information on the study variables (Ember and Ember, 2009). Panel data for this study was obtained from the 35 petroleum marketing firms' annual reports which are regularly submitted to the ERC. Dawson (2009) notes that secondary data collection may also involve collection and use of information other past studies on the subject matter. Khan (2012) and Saaedi and Mahmoodi (2011) concurred that the use panel data especially when investigating financial structure and profitability or even capital structure and firm financial performance.

To ensure the panel data that was collected various quality test were conducted as explained below besides using only audited accounts since these accounts are verified and counterchecked by a credible internationally recognized audit firm. Additionally, closed ended questions were adopted to enhance content validity and research permission letters and company logos used to enhance face validity firm in Kenya. Based on the scope of this study (petroleum marketing companies), the researcher found it sound to analyze statements from 2007 to 2016 using panel method.

\section{Findings}

The study sought to examine the effect of retained earnings finance on profitability of petroleum companies in Kenya. These ranged from the firm preference for long term debt to debt financing and interest rates. The following series of tables show the results of the Likerts scale on various commercial debt finance characteristics.

Table 4. 1: Shareholders preference for employment of retained earnings

\begin{tabular}{llll}
\hline & Frequency & Percent & Cumulative Percent \\
\hline Strongly Disagree & 8 & 27.6 & 27.6 \\
Disagree & 7 & 24.1 & 51.7 \\
Neutral & 6 & 20.7 & 72.4 \\
Agree & 8 & 27.6 & 100.0 \\
Strongly Agree & 0 & 0.0 & \\
\hline Total & $\mathbf{2 9}$ & $\mathbf{1 0 0 . 0}$ & \\
\hline
\end{tabular}

From the findings $27.6 \%$ of the respondents agree most shareholders prefer employment of retained earnings, $27.6 \%$ and $24.1 \%$ of the respondents strongly disagreed and disagreed respectively. This yields a cumulative $51.7 \%$ of the respondents disagreeing to the statement, $20.7 \%$ of the respondents were neutral about the statement.

This above position however contradicts a view by Chasan, (2012) and Orwel, (2010) who acknowledged that there is a positive relationship between retained and firm earnings hence the high preference of its employment as it doesn't attract interest and its related risks. Further still these findings fail to explain the argument that enterprises exist for the purpose of creating value different stakeholders ranging from; shareholders, those with investments in the firm, clients both internal and external, employees, among others (Ball, 2013). 
Table 4. 2: Retained earnings a reliable source of finance on regular basis

\begin{tabular}{llll}
\hline & Frequency & Percent & Cumulative Percent \\
\hline Strongly Disagree & 3 & 10.3 & 10.3 \\
Disagree & 4 & 13.8 & 24.1 \\
Neutral & 3 & 10.3 & 34.4 \\
Agree & 19 & 65.6 & 100.0 \\
Strongly Agree & 0 & 0.0 & \\
\hline Total & $\mathbf{2 9}$ & $\mathbf{1 0 0 . 0}$ & \\
\hline
\end{tabular}

From the findings $65.6 \%$ of the respondents agree that retained earnings are reliable source of finance as the firm retains on regular basis. Thirteen point three $(13.8 \%)$ and $10.3 \%$ of the respondents disagree over the same statement. This yields a cumulative $24.1 \%$ of the respondents disagreeing to the statement however, $10.3 \%$ did not give any opinion.

These findings uphold the notion that manager's preference that the firm should retain more funds to ensure growth and address gaps in the current potential opportunities as perceived by management through utilization of what has been given back to the business (Orwel, 2010)

Table 4. 3: All retained earnings have been reinvested back to the business - last 10 years

\begin{tabular}{llll}
\hline & Frequency & Percent & Cumulative Percent \\
\hline Strongly Disagree & 6 & 20.7 & 20.7 \\
Disagree & 8 & 27.6 & 48.3 \\
Neutral & 8 & 27.6 & 75.9 \\
Agree & 7 & 24.1 & 100.0 \\
Strongly Agree & 0 & 0.0 & \\
\hline Total & $\mathbf{2 9}$ & $\mathbf{1 0 0 . 0}$ &
\end{tabular}

From the findings $27.6 \%$ of the respondents were neutral that all retained earnings have been reinvested back to the business over the last 10 years, $27.6 \%$ and $20.7 \%$ of the respondents disagreed withthe same statement. This yielded a cumulative $48.3 \%$ of the respondents disagreeing to the statement. The findings above uphold and concur with findings by Dinayak, (2014) and Campbell (2012) who acknowledged that the main idea behind retention of profits is that, it facilitates fast growth rate in among firms that have embraced this practice.

\subsubsection{Firm's Profitability}

Firms' profitability was the study's dependent variable. It is anticipated that variation in some or all aspect of the previously discussed determinants would result to some variation in the financial performance of petroleum companies in Kenya. In order to be able to relate this variable to the determinants (independent variables), the study sought to delve into the characteristics of this variable, for a better insight. The following series of tables show the results of the Likert-scale on the various aspects of profitability.

Table 4. 4: The firm has had an increase in ROA for the last 10 years

\begin{tabular}{llll}
\hline & Frequency & Percent & Cumulative Percent \\
\hline Strongly Disagree & 7 & 24.1 & 24.1 \\
Disagree & 8 & 27.6 & 51.7 \\
Neutral & 7 & 24.1 & 75.8 \\
Agree & 7 & 24.1 & 100.0 \\
Strongly Agree & 0 & 0.0 & \\
\hline Total & $\mathbf{2 9}$ & $\mathbf{1 0 0 . 0}$ & \\
\hline
\end{tabular}

From the findings $24.1 \%$ of the respondents strongly disagree that the firm has had an increase in ROA for the last 5 years, 27.6 disagreed thus cumulatively $51.7 \%$ disagreed. On the other hand, $24.1 \%$ of the respondents did not 
give any opinion while $23.0 \%$ agreed over the same statement. The above findings contradicted what Fabozzi \& Peterson (2013) found out as the scholar found both an increase and decrease in profitability over years depending on the prevailing market conditions.

\section{Table 4. 5: Firm has better ROA than industry average for the last 10 years}

From the findings $27.7 \%$ of the respondents were indifferent about petroleum firms having had better ROA than industry average for the last 10 years, $24.1 \%$ of the respondents strongly disagreed, while $24.1 \%$ agreed over the same statement.

\begin{tabular}{llll}
\hline & Frequency & Percent & Cumulative Percent \\
\hline Strongly Disagree & 7 & 24.1 & 24.1 \\
Disagree & 7 & 24.1 & 48.2 \\
Neutral & 8 & 27.7 & 75.9 \\
Agree & 7 & 24.1 & 100.0 \\
Strongly Agree & 0 & 0.0 & \\
\hline Total & $\mathbf{2 9}$ & $\mathbf{1 0 0 . 0}$ & \\
\hline
\end{tabular}

These findings were mixed as over time, ROA as an indicator of net revenue in comparison with the industry average assets in a given financial year has been both good and bad (Williams, 2010) has been going up and down hence the difference in the findings.

Table 4. 6: Petroleum firms have had an increase in ROE for the last 10 years

\begin{tabular}{llll}
\hline & Frequency & Percent & Cumulative Percent \\
\hline Strongly Disagree & 7 & 24.1 & 24.1 \\
Disagree & 7 & 24.1 & 48.2 \\
Neutral & 7 & 24.1 & 72.3 \\
Agree & 8 & 27.7 & 100.0 \\
Strongly Agree & 0 & 0.0 & \\
\hline Total & $\mathbf{2 9}$ & $\mathbf{1 0 0 . 0}$ & \\
\hline
\end{tabular}

According to Table 4.18, 27.7\% of the respondents were in agreement with the statement that the firm has had an increase in ROE for the last 10 years while $24.1 \%$ were neutral. $24.1 \%$ of the respondents strongly disagreed; another $24.1 \%$ disagreed with the statement thus cumulatively $48.2 \%$. The proportions yield a mean of 2.583 indicating "neutral" with majority not giving any opinion to it (mode $=3$ ).

The findings in table 4.17 above contradicted the findings of Gul et al., (2011) and Khrawish, (2011) which had noted that net profit margin as compared to equity has been unstable over time due to unstable market conditions.

Table 4. 7: Correlation Analysis for variable commercial loans

\begin{tabular}{lll}
\hline & ROA & RE \\
\hline ROA & 1.0000 & \\
RE & 350 & 1.0000 \\
& -0.1336 & 350 \\
\hline
\end{tabular}

Pairwise correlation coefficient was used to gauge the relationship between retrained earnings and profitability. The results indicated that retained earning finance has a significant inverse relationship with ROA. This was indicated by Table 4.28 , which show that the $p$-value was at $p=0.000$ and this met the threshold since $p<0.05$. The inverse relationship was represented by correlation coefficient of 0.2652 . The results corroborates with the findings by Maina and Kodongo (2013) and Ishaya and Abduljeleel (2014) who agreed that equity dividend ratio can be imperative when measured by variable proxies.

The study sought to establish the effect of retained earnings finance on profitability of petroleum firms in Kenya. The results indicated an inverse and insignificant relationship between retained earnings finance and profitability at $1 \%$ significance level. This is evidenced by the beta coefficient of -0.018 and a corresponding $p$-value of 0.975 under equations 1 . The results signify that during the period of study, increasing use of retained earnings finance 
did not increase or reduce the profitability of petroleum firms in Kenya; implying an improvement in their financial status.

\section{Conclusion and Recommendations}

The study was to establish the effect of retained earning finance on profitability of petroleum companies in Kenya. This was achieved by analyzing how employment of retained earnings finance affected the ROA of the companies under study. The study found that during the analysis period, retained earnings finance had an inverse and insignificant effect on profitability of petroleum companies in Kenya.

Thirdly, the study recommends that in configuring their financial structure, financing managers of petroleum firms should prioritize the use of internally generated capital such as retained earnings and reserves ahead of externally issued equity. There is need to institute appropriate regulatory mechanisms meant to cushion investors from loss of their hard earned wealth and hence restore confidence in their investments. The study recommends a similar study be carried out within larger jurisdictions that could present unique economic and regulatory dynamics.

\section{References}

Akoto, R.K., Awunyo- Victor, D., and Angmor, P.L. (2013). Working capital management and profitability: Evidence from Ghanaian petroleum manufacturing firms. Journal of Economics and International Finance, 5(9), 373-379.

Baffes, J., M. A. Kose, F. Ohnsorge and M. Stocker: (2015). The Great Plunge in Oil Prices - Causes, Consequences, and Policy Responses, Policy Research Note No.1.

Ball, R. (2013). Accounting Informs Investors and Earnings Management is Rife: Two Questionable Beliefs. Accounting Horizons, 27(4), 847-53.

Baimwera, B., \& Muriuki, A. (2014). Analysis of corporate financial distress determinants: A survey of nonfinancial firms listed in the NSE. International Journal of Current Business and Social Sciences, 1 (2), 58-80.

Bhutta, N.T. \& Hasan, A. (2013). Impact of firm specific factors on profitability of firms in food sector. Open journal of accounting 2: 19-25

Castro, P. C., Tascón, M. T., \& Amor-Tapia, B. (2011). Dynamic analysis of capital structure in technological firms based on the firms' life cycle stages. 107 No. 5, p. 16

Ezazi, M., Sadeghi sharif, S., Alipour, M. and Amjadi, H.(2011). The Effect of financial Structure on Share Price Volatility of Listed Companies in Tehran Stock Exchange: An Empirical Evidence of Iran. International Journal of business and Social Science, 5(2), 45-62.

Gakure R., Cheluget, K. J. Onyango, J.A, \& Keraro, V. (2012).Working capital management and profitability of manufacturing firms petroleum at the Nairobi stock exchange. Prime Journal of Business Administration and Management (BAM), 2(9), 680-686.

Jape, S. S., \& Korde, T. (2013). Study of established corporate finance tools and its need in financial decision making of companies, with emphasis on capital budgeting and capital structure (with reference to Mumbai based companies: period-2002-2012). International Journal of Management and Social Sciences Research, 2(10), 15-18

Jordan, R. W. (2003). Fundamentals of Corporate Finance, (6thed).Hoboken, NJ: McGraw-Hill.

Kaumbuthu, A.J. (2011). The effect of capital structure and financial performance: a study of firms listed under industrial and allied sector at the NSE, Unpublished -Dissertation, Nairobi: University of Nairobi. Retrieved from http://erepository.uonbi.ac.ke.

Khan, A., Kaleem, A., Mian Sajid Nazir, M.S. (2012). Impact of Financial Leverage on Agency cost of Free Cash Flow: Evidence from the Manufacturing sector of Pakistan. Journal of Basic and Applied Scientific Research, 2, 7, 6694- 6700.

Kimeli, S. K. (2012). Analysis of effects of working capital management on profitability of manufacturing companies: A case study of listed manufacturing companies on Nairobi Securities Exchange (NSE). Thesis. Kabarak University.

Kothari, C. (2004). Research Methodology: Methods and Techniques. (2nd ed.). New Delhi, India: New age International Publishers.

Maina, L., \& Kondongo, O. (2013). Capital Structure and Financial Performance in Kenya: Evidence from Firms Listed at the Nairobi Securities Exchange. Paper Presented at the Jomo Kenyatta University of Science and Technology Research Conference, Kenya

Myers, S. C., \& Majluf N. S. (1984). Corporate financing and investment decisions when firms have information that investors do not have. Journal of Financial Economics.

Nyabwanga, R.N., Ojera, P., Lumumba, M., Odondo, A.J., and Otieno, S. (2012). Effect of working capital management practices on financial performance: A study of small scale enterprises in Kisii South District, Kenya. African Journal of Business Management, 6 (18) 5807-5817. 
Omesa, N. W., Maniagi, G. M., Musiega, D., and Makori, G.A. (2013). Working capital management and corporate performance: Special reference to manufacturing firms on Nairobi Securities exchange. International Journal of Innovative Research and Development, 2(9), 177-183.

Saeedi, A and Mahmoodi I, (2011), Capital Structure and Firm Performance: Evidence from Iranian firms, International Research Journal of Finance and Economics, 70: 21-28.

Shubita, M. F., \& Alsawalhah, J.F. (2012). The Effect of Capital Structure and Profitability. International Journal of Business and Social Science, 3(16).

Wamugo, Mwangi, Makau, Muathe Stephen, and Kosimbei, George (2014) "Relationship between Capital Structure and Performance of Non-Financial Companies Listed In the Nairobi Securities Exchange, Kenya". Global Journal of Contemporary Research in Accounting, Auditing and Business Ethics, Vol: 1 Issue 2.

Vural, G., Sökmen, A. G., \& Çetenak, E. H. (2012). Effects of working capital management on firm's performance: evidence from Turkey. International Journal of Economics and Financial Issues, 2(4), 488495.

Wen, W. (2010) Ownership Structure and Banking Performance: New Evidence in China. Universitat Autònoma de Barcelona. 